\title{
Muscular dystrophies, the cytoskeleton and cell adhesion
}

\author{
Heather J. Spence, Yun-Ju Chen, and Steven J. Winder*
}

\begin{abstract}
Summary
Muscular dystrophies are associated with mutations in genes encoding several classes of proteins. These range from extracellular matrix and integral membrane proteins to cytoskeletal proteins, but also include a heterogeneous group of proteins including proteases, nuclear proteins, and signalling molecules. Muscular dystrophy phenotypes have also become evident in studies on various knockout mice defective in proteins not previously considered or known to be mutated in muscular dystrophies. Some unifying themes are beginning to emerge from all of these data. This review will consider recent advances in our understanding of the molecules involved and bring together data that suggest a role for the cytoskeleton and cell adhesion in muscular dystrophies. BioEssays 24:542-552, 2002.

(c) 2002 Wiley Periodicals, Inc.
\end{abstract}

\section{Introduction}

The muscular dystrophies are a group of inherited disorders of muscle proteins characterised by progressive muscle degeneration. The high degree of organisation in specialised cells and tissues such as striated muscle makes them particularly susceptible to the effects of mutations. This is because small changes caused by mutations are propagated throughout the ordered lattice resulting in tissue-wide effects. These aberrations are most apparent in mutations in structural and contractile proteins of the highly ordered sarcomere. However, in addition to maintaining sarcomeric structure, the muscle fibre must also maintain the sarcoplasmic reticulum and t-tubule system, an extensive network of mitochondria, and connec-

Institute of Biological and Life Sciences, Glasgow Cell Biology Group, Scotland.

${ }^{*}$ Correspondence to: Steven Winder, Institute of Biological and Life Sciences, Glasgow Cell Biology Group, Davidson Building, University of Glasgow, Glasgow G12 8QQ, Scotland.

E-mail: s.winder@bio.gla.ac.uk

DOI 10.1002/bies.10098

Published online in Wiley InterScience (www.interscience.wiley.com.)

Abbreviations: BMD, Becker muscular dystrophy; CMD, congenital muscular dystrophy; DGC, dystrophin glycoprotein complex; DMD, Duchenne's muscular dystrophy; FAK, focal adhesion kinase; LGMD, limb-girdle muscular dystrophy; NMJ, neuromuscular junction; nNOS, neuronal nitric oxide synthase tions between myofibrils and the sarcolemma and between sarcolemma and the extracellular matrix. The highly ordered nature of the sarcomere is also reflected in the ordered nature of cytoskeletal and membrane proteins involved in linking the contractile apparatus to the membrane and extracellular matrix. These ordered connections occur at several levels along the sarcomere and are most evident as bands running circumferentially around muscle fibres mostly coincident with Z-lines, but also with the M-line. Striations coincident with the $Z$-lines and rich in proteins such as $\alpha$-actinin, vinculin, talin and the transmembrane adhesion receptors integrins, have been termed costameres ${ }^{(1)}$ (Fig. 1). Costameres have been defined as regions of sarcolemmal attachment to the extracellular matrix, and as being important for the conduction of force during muscle contraction. ${ }^{(1)}$ Other regions of connectivity have been defined in muscle in addition to the costameres; these include the myotendinous junction and neuromuscular junction (NMJ), see Ref. 2 for a comprehensive review. Not all the proteins in costameres and myotendinous junction regions are involved in maintaining the connectivity between cytoskeleton and extracellular matrix, e.g. ion channels, but within these regions of connectivity there are three subsets of cytoskeletal membrane attachments: the spectrin-based, the dystrophin-based and the integrin-based. Whilst the dividing lines between these complexes are becoming increasingly blurred, mutations leading to a wide range of myopathies, atrophies and dystrophies arise in many of these systems. This discussion is largely restricted to muscular dystrophies that arise through perturbations in the connectivity between the cytoskeleton, sarcolemma and extracellular matrix.

\section{Muscular dystrophy and the dystrophin glycoprotein complex}

Since the identification of the dystrophin gene as the source of the genetic defect in Duchenne muscular dystrophy (DMD) and its positional cloning by Kunkel and colleagues in the late 1980 s, ${ }^{(3,4)}$ considerable effort has been expended on elucidating the molecular associations of the dystrophin protein. These efforts have led to the identification of a large group of transmembrane and associated proteins known collectively as the dystrophin glycoprotein complex (DGC) ${ }^{(5-7)}$ (Fig. 2). Subsequent molecular and genetic analysis of many of these associated proteins has in turn revealed their involvement in other clinically distinct muscular dystrophies, ${ }^{(8)}$ Table 1. Furthermore, mutations in the gene encoding the $\alpha-2$ chain of 


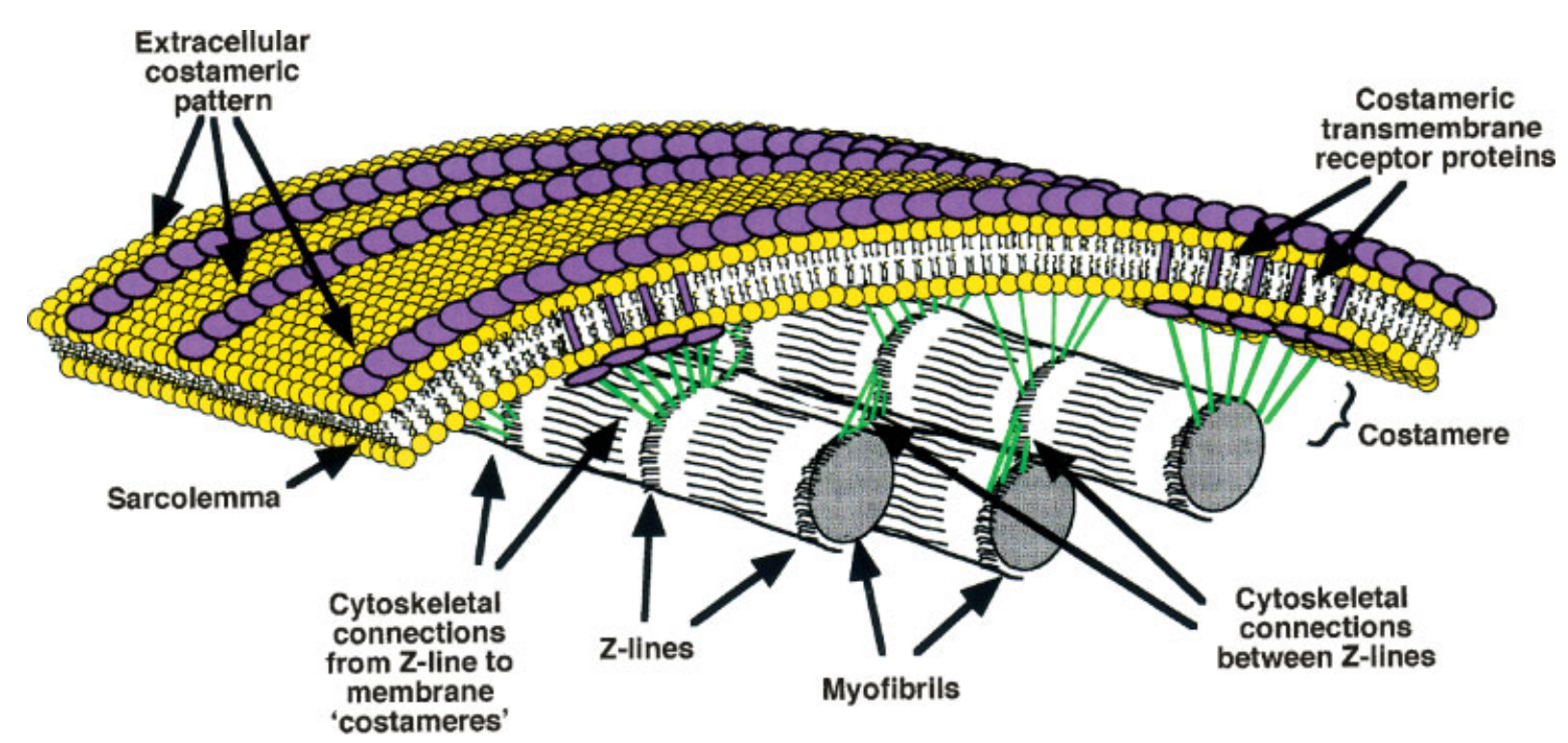

Figure 1. Costameric organisation in skeletal muscle. Scheme showing the relationship between the Z-lines of myofibrils, costameres and the costameric arrangement of membrane proteins, either ion channels or adhesion receptors. Individual myofibrils are shown in black and white; for cytoskeletal connections, actin and desmin filaments and associated proteins are shown in green, and transmembrane anchoring proteins in purple. The sarcolemma is in yellow.

the extracellular matrix protein laminin, the muscle isoform of laminin to which the DGC is anchored in the extracellular matrix, give rise to yet another form of muscular dystrophy congenital muscular dystrophy (CMD) ${ }^{(8)}$ These findings have led to the paradigm that, in many of these muscular dystrophies, the principal defect is the loss of a mechanical link between the cytoskeleton and the extracellular matrix, which somehow leads to muscle fragility, contraction-induced damage and necrosis. ${ }^{(9)}$ Whilst an attractive hypothesis, this argument cannot be universally applied, suggesting that other factors contribute to the disease process including the perturbation of signalling pathways, (see discussions under 'Dystrobrevins and Syntrophins' and 'Mechanisms of Muscular Dystrophy').

\section{Dystrophin}

Dystrophin serves as a cytoskeletal linker between the subsarcolemmal actin cytoskeleton and dystroglycan. Dystroglycan is a laminin receptor comprising $\beta$-transmembrane and $\alpha$-extracellular subunits (Fig. 2). The $\alpha$-dystroglycan subunit in turn binds several extracellular matrix components including laminin, perlecan and agrin, see Ref. 10 for recent review. Thus it can be seen that the DGC forms a direct link between the actin cytoskeleton and the extracellular matrix and breaks in this link, at any one of several levels, give rise to muscular dystrophy phenotypes. Loss of dystrophin function, which completely severs the link between actin and the membrane, leads to DMD. Interestingly, in the absence of dys- trophin, there is a concomitant loss of other DGC proteins, ${ }^{(5,11)}$ effectively removing all components from the link. The importance of dystrophin in this link, however, was nicely illustrated by the overexpression of Dp71, a short C-terminal isoform of dystrophin that contains the binding sites for dystroglycan but not actin. Transgenic expression of Dp71 in $m d x$ mice (see Table 2) that naturally lack dystrophin, restored the DGC components but failed to correct the muscular dystrophy phenotype ${ }^{(12,13)}$ clearly pointing to the importance of the actin cytoskeleton. However, other transgenic approaches have suggested that the amino-terminal actinbinding domain of dystrophin was not important for dystrophin function, ${ }^{(14)}$ as constructs lacking this region were still able to rescue the muscular dystrophy phenotype when expressed in $m d x$ mice. A similar picture is evident in studies of patients with Becker muscular dystrophy (BMD), a milder allelic variant of DMD, where some altered but partially functional protein is expressed. ${ }^{(15,16)}$ These findings seem somewhat paradoxical; if the dystrophin-mediated link from the actin cytoskeleton to dystroglycan is so crucial, then one would expect mutations in the domains that bind to actin and dystroglycan to have the severest disease phenotype. Whilst this is certainly true for mutations in the carboxy-terminal regions of dystrophin that bind to dystroglycan, giving a phenotype similar in severity to DMD where dystrophin is completely absent, it is not the case for mutations in the amino-terminal actin-binding region, where mutations cause a milder BMD phenotype. ${ }^{(15,16)}$ The reason for this inconsistency is due to the presence of at least 


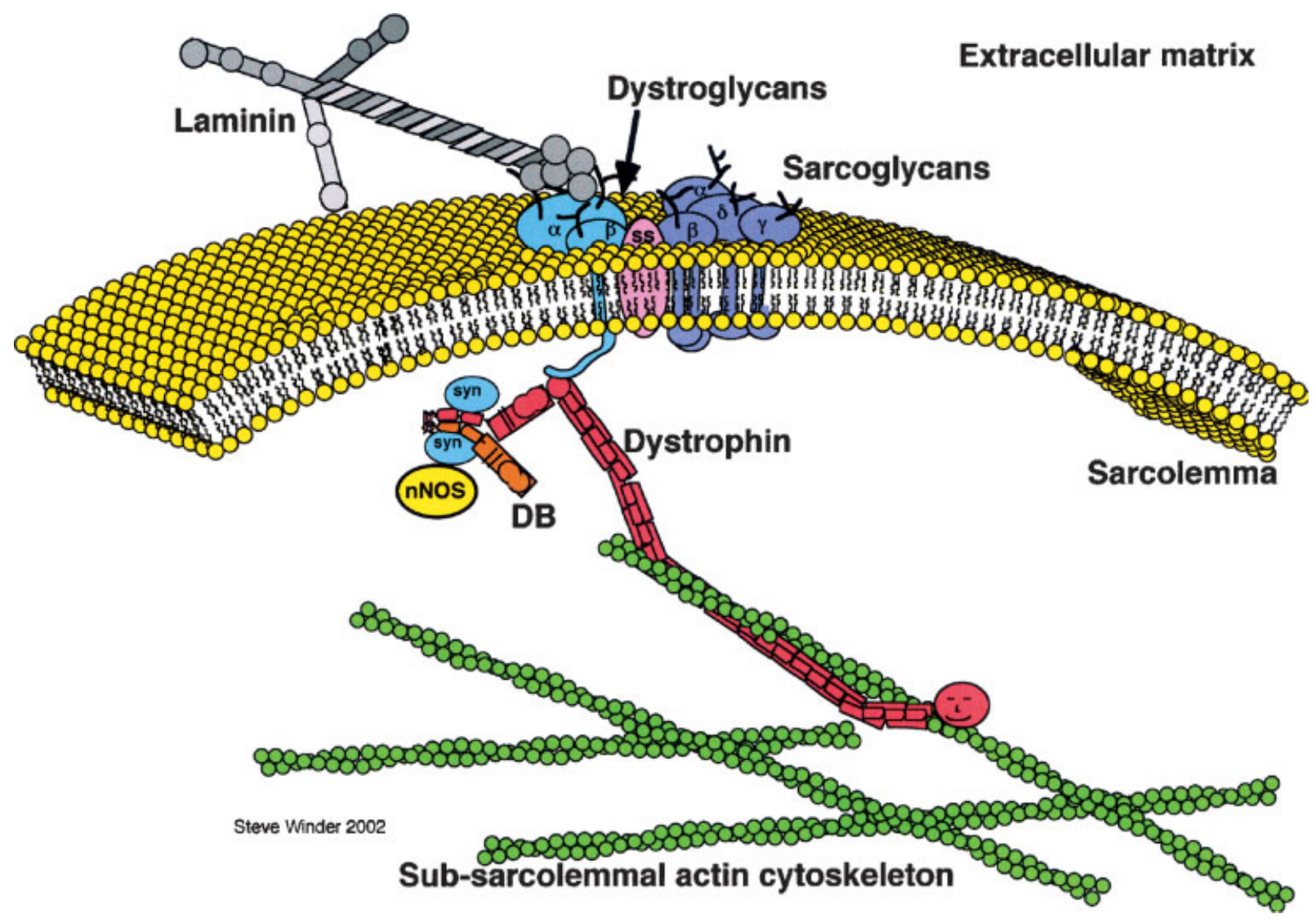

Figure 2. The dystrophin glycoprotein complex of skeletal muscle. Scheme showing a potential arrangement of DGC components in the sarcolemma and sub-sarcolemmal actin cytoskeleton. Laminin, grey; dystroglycans ( $\alpha-, \beta-)$, light blue; sarcospan (SS), pink; sarcoglycans $(\alpha-, \beta-, \gamma-, \delta$-), lilac; syntrophin (syn), light blue; dystrobrevin (DB), orange; neuronal nitric oxide synthase (nNOS, yellow; dystrophin, magenta; actin, green. Associations shown may not all occur at the same time or in the same location in the sarcolemma.

Table 1. Muscular dystrophies, genes and proteins

\begin{tabular}{|c|c|c|c|c|}
\hline Name & Chromosome & Gene & Protein & References \\
\hline Duchenne & Xp21.2 & DMD & Dystrophin & (4) \\
\hline Congenital & 6q22 & LAMA2 & Laminin $\alpha 2$ & (77) \\
\hline Emery-Dreifuss & Xq28 & EMD & Emerin & (78) \\
\hline Emery-Dreifuss & $1 \mathrm{q} 11$ & LMNA & Lamin A/C & (79) \\
\hline LGMD1A & $5 q 31$ & TTID & Myotillin & (61) \\
\hline LGMD1B & $1 q 11$ & LMNA & Lamin $A / C$ & (80) \\
\hline LGMD1C & $3 p 25$ & CAV3 & Caveolin 3 & (67) \\
\hline LGMD1E & $7 q$ & FLN2? & Filamin 2? & (65) \\
\hline LGMD2A & $15 q 15.1$ & CAPN3 & Calpain 3 & (66) \\
\hline LGMD2B & $2 \mathrm{p} 13$ & DYSF & Dysferlin & $(81,82)$ \\
\hline LGMD2C & $13 q 12$ & SGCG & $\gamma$-sarcoglycan & (83) \\
\hline LGMD2D & $17 q 12$ & SGCA & $\alpha$-sarcoglycan & (84) \\
\hline LGMD2E & $4 q 12$ & SGCB & $\beta$-sarcoglycan & (85) \\
\hline LGMD2F & $5 q 31$ & SGCD & $\delta$-sarcoglycan & (86) \\
\hline LGMD2G & $17 q 11-12$ & TCAP & Telethonin & (62) \\
\hline
\end{tabular}

\section{BioEssays 24.6}


Table 2. Some mouse mutants and knockouts of muscular dystrophy associated proteins

\begin{tabular}{|c|c|c|c|}
\hline Name & Protein(s) deleted & Skeletal dystrophy phenotype & References \\
\hline$m d x$ & Dystrophin ${ }^{*}$ & Mild & (87) \\
\hline UTRN $^{-1-}$ & Utrophin & None but NMJ phenotype & $(88,89)$ \\
\hline$m d x / \mathrm{UTRN}^{-1-}$ & Dystrophin/utrophin & Severe & $(90,91)$ \\
\hline dy & $\alpha 2$ laminin & Severe & (92) \\
\hline $\mathrm{DAG} 1^{-/-}$ & $\alpha / \beta$-dystroglycan & Embryonic lethal & (27) \\
\hline $\mathrm{DAG}^{-1-}$ Chimera & $\alpha / \beta$-dystroglycan & Severe & (28) \\
\hline $\mathrm{Scga}^{-1-}$ & $\alpha$-sarcoglycan & Moderate & (93) \\
\hline $\mathrm{Scgb}^{-1-}$ & $\beta$-sarcoglycan & Moderate & (94) \\
\hline $\mathrm{Scgg}^{-1-}$ & $\gamma$-sarcoglycan & Severe & (95) \\
\hline $\mathrm{Scgd}^{-1-}$ & $\delta$-sarcoglycan & Severe & (96) \\
\hline $\mathrm{aDbn}^{-1-}$ & $\alpha$-dystrobrevin & Mild & (31) \\
\hline $\mathrm{aSyn}^{-1-}$ & $\alpha$-syntrophin & None (NMJ phenotype) & $(38,39)$ \\
\hline $\mathrm{Sspn}^{-1-}$ & Sarcospan & None & (97) \\
\hline
\end{tabular}

$m d x$ and $d y$ mice are not true nulls but lack functional full-length protein.

two, well-separated strong actin-binding sites, one present at the amino terminus and one in the coiled-coil region, which serve to delimit a large region of dystrophin that can interact with $\mathrm{F}$-actin in a co-operative manner analogous to F-actin side-binding proteins like tropomyosin or nebulin. ${ }^{(17,18)}$ Deletion of only one of these sites is presumably insufficient in itself to abolish all actin-binding function in dystrophin, thus some connectivity between actin and extracellular matrix is maintained. Interestingly the autosomal homologue of dystrophin, utrophin, whilst biochemically equivalent in most respects, ${ }^{(19,20)}$ appears to lack this function, ${ }^{(21)}$ though it can functionally replace dystrophin and reduce the dystrophic phenotype when overexpressed in $m d x$ mice. ${ }^{(22)}$ Most recently it has been demonstrated that lack of dystrophin not only leads to the loss of other DGC components but also, and perhaps rather surprisingly, a dramatic reduction in the affinity of any membrane protein-linkage to the entire subsarcolemmal actin cytoskeleton. ${ }^{(23)}$ It is perhaps therefore not too surprising that muscle cell integrity is compromised in the absence of dystrophin, as without this link to the subsarcolemmal actin, even in the presence of integrins that can link the membrane to actin via $\alpha$-actinin and vinculin ${ }^{(24)}$ and ion channels that can link the membrane to actin via spectrin, ${ }^{(25)}$ these latter connections would not appear to be strong enough to withstand mechanical forces, or perhaps more likely do not confer appropriate signalling properties in response to contraction to withstand mechanical forces.

\section{Dystroglycan}

Dystroglycan is a ubiquitously expressed laminin receptor, with a role in basement membrane assembly, ${ }^{(26)}$ thus it is perhaps not surprising that mice deficient for dystroglycan were not viable. ${ }^{(27)}$ A similar finding has been observed for deletion of other cell adhesion molecules such as integrins (see below). Chimeric deletion of muscle dystroglycan, the main link between the DGC and both the actin cytoskeleton and the extracellular matrix, did lead to muscular dystrophy. ${ }^{(28)}$ To date however, genetic lesions in the dystroglycan gene have not been associated with any human disorder. For recent comprehensive review see Ref. 10.

\section{Sarcoglycans}

The limb-girdle muscular dystrophies (LGMD) are a heterogeneous group of muscular dystrophies, several of which were mapped to genes for the sarcoglycan components of the DGC (Fig. 2). Precisely how mutations in any one of the four sarcoglycans (see Table 1) leads to muscular dystrophy is not clear, but transgenic mice with knockouts of individual sarcoglycans (Table 2) have begun to provide some molecular details of disease pathology. Loss of sarcoglycan expression does not lead to a complete loss of DGC components as in dystrophin deficiency, though DGC components may be reduced. It does however selectively reduce all sarcoglycans at the sarcolemma. This has led to the suggestion that sarcoglycans may also perform a separate role in maintaining muscle integrity, perhaps in a non-structural or signalling capacity. This hypothesis is supported by evidence that sarcoglycans, whilst clearly members of the DGC, form a biochemically distinct subset of the DGC inasmuch as they can be differentially extracted as a subcomplex from the dystroglycans and the rest of the DGC, ${ }^{(29)}$ and appear to be synthesised and assembled as a complete unit. ${ }^{\left({ }^{30)}\right.}$ Clear evidence of a role for sarcoglycans in signalling has not yet been forthcoming, but sarcoglycan deficiency in mice does involve other muscle groups including cardiac and vascular, to an extent not seen in the dystrophinopathies, (see also 'Myofibrillar proteins' below).

\section{Dystrobrevin and syntrophins}

Dystrobrevin is a cytoplasmic protein associated with the carboxy-terminus of dystrophin, and whilst it is not known to be associated with human disease, mice lacking $\alpha$-dystrobrevin 
displayed a muscular dystrophy phenotype. ${ }^{(31)}$ Dystrobrevin is able to associate with both syntrophins and dystrophin via coiled-coil interactions, ${ }^{(32-34)}$ and disruption of these associations in turn affect the recruitment of neuronal nitric oxide synthase (nNOS) to the sarcolemma via syntrophins, ${ }^{(35)}$ implicating nitric oxide synthase signalling in the pathogenesis of muscular dystrophy. nNOS levels are also reduced in DMD. ${ }^{(31,35,36)}$ This might simply be thought to be a consequence of disruption of the binding site for nNOS due to the loss of syntrophins and dystrobrevin from the sarcolemma concomitant with the loss of the DGC but, interestingly, loss of $\alpha$-dystrobrevin from muscle does not lead to loss of other dystrophin glycoprotein complex proteins. It is concluded from this that it is solely the loss of nNOS from the complex that is responsible for the muscular dystrophy phenotype in this case. The situation is not quite so simple however, because mice deficient in nNOS do not exhibit muscular dystrophy, ${ }^{(37)}$ and mice lacking $\alpha$-syntrophin also lack sarcolemmal nNOS, but have no overt muscle phenotype. ${ }^{(38)}$ This apparent paradox is probably best explained by nNOS binding only to a complex containing dystrobrevin and $\alpha$-syntrophin (see discussion in Ref. 36). Nevertheless, nNOS is strongly implicated in the pathology of DMD. More detailed analysis of $\alpha$-syntrophindeficient mice also revealed a NMJ defect with reduced postjunctional folds, fewer acetylcholine receptors and the specific absence of utrophin despite the presence of $\beta 2$-syntrophin, dystrophin and dystrobrevin. ${ }^{(39)}$ Previous work suggesting that $\alpha$-syntrophin was required for the localisation of sodium channels at the sarcolemma have recently been challenged, mice expressing an $\alpha$-syntrophin mutant lacking the PDZ domain, which was shown biochemically to be required for sodium channel binding, had normal levels of sodium channels at the sarcolemma, but did show reduced levels of nNOS and an aquaporin. ${ }^{(40)} \mathrm{A}$ further level of complexity is the finding that $\beta 2$-syntrophin associates with serine/threonine kinases, some of which are known to be microtubule associated. ${ }^{(41)}$ These microtubule-associated and syntrophin-associated serine/ threonine kinases add another level of signalling potential to the dystrophin and utrophin glycoprotein complexes, and may also serve to connect these complexes to the microtubulebased cytoskeleton. ${ }^{(41)}$ Moreover, $\alpha 1$-syntrophin interacts with the stress-activated protein kinase-3 (ERK6) via its PDZ domain, ${ }^{(42)}$ leading to the phosphorylation of $\alpha 1$-syntrophin. The precise role of $\alpha 1$-syntrophin phosphorylation is not clear, but expression profiling in DMD not only revealed a 14-fold reduction in $\alpha 1$-syntrophin expression, but also 10-fold decrease in ERK6 expression (amongst many other things), ${ }^{(43)}$ suggesting some sort of co-ordinated regulation between stressactivated protein kinase-3, $\alpha 1$-syntrophin and dystrophin. ${ }^{(43)}$

\section{Integrins}

Mutations in integrins are not generally known to be associated with human disease. Mice deficient for integrin subunits usually have preimplantation defects or are embryonic lethal. The localisation of integrin subunits to regions of cell adhesion in muscle, i.e. myotendinous junction and costameres as well as to the neuromuscular junction, strongly support a role for integrins in maintaining adhesion links in muscle. It is perhaps not surprising therefore that deletion of individual integrin subunits in mouse leads to dystrophic phenotypes. From experiments conducted on chimeric mice or embryonic stem cells, it is clear that there is a role for integrins in the organisation of both basement membrane and the cytoskeleton in muscle cells. In particular, $\alpha 5 \beta 1$ integrins were shown to localise with dystrophin during muscle development. ${ }^{(44)}$ Interestingly, it has been reported that $\alpha 5 \beta 1$ integrin may also be involved in signalling to the dystrophin glycoprotein complex via Src or focal adhesion kinase (FAK), resulting in the specific phosphorylation of $\alpha$ - and $\gamma$-sarcoglycans in cultured L6 myocytes. ${ }^{(45)}$ Though the consequences of these phosphorylation events are unclear. Integrin $\alpha 5$-deficient mice are embryonic lethal, whereas mice chimeric for integrin $\alpha 5$, with a high level of $\alpha 5$ integrin-deficient muscle fibres, develop a very early muscular dystrophy phenotype. ${ }^{(46)}$ Mutations in the muscle-specific $\alpha 7$ integrin are the cause of a congenital myopathy. ${ }^{(47)}$ The disruption of the integrin $\alpha 7$ subunit in mice surprisingly did not cause lethality; however, mice did exhibit a novel form of muscular dystrophy. ${ }^{(48)}$ In addition, studies have implicated $\alpha 7 \beta 1$ integrin in the organisation of the muscle basement membrane. ${ }^{(49)}$ What the precise role of integrins are in the overall connections between cytoskeleton and extracellular matrix in muscle awaits further analysis. What is clear, however, is that integrins play a crucial role in concert with dystroglycan in the organisation of the extracellular matrix and, in particular, the formation of the muscle basal lamina. ${ }^{(49,50)}$ Recent evidence suggests cooperativity between extracellular matrix protein receptors and organisation of the extracellular matrix. Dystroglycan appears to bind initially to laminin followed by laminin associating with $\beta 1$ integrins. Dystroglycan binds to specific laminin G-domains (LG), crystallographic studies of these LG domains reveal the structural basis for dystroglycan-laminin interactions. ${ }^{(51,52)}$ Furthermore, these structural studies also reveal the molecular basis for dystroglycan interaction with the related LG domains from agrin and perlecan. A network of laminin, dystroglycan and integrins then undergoes rearrangements with associated reorganisation of the actin cytoskeleton. ${ }^{(49,50)}$ Consequently, a reciprocal distribution of dystroglycan and integrin arises with corresponding reciprocal arrangements in the cytoskeleton associated with these transmembrane receptors. Perlecan, another ligand for dystroglycan, has also been implicated in the process, such that $\beta 1$ integrins and perlecan are required for the overall assembly of the laminin matrix after it was bound to the cell by dystroglycan. ${ }^{(50)}$ All these studies clearly point to a role for cell adhesion in maintenance of muscle integrity. Furthermore, depending upon the particular cell adhesion receptors

\section{BioEssays 24.6}


employed, then different aspects of the cytoskeleton are also involved in binding to these receptors. Some of the molecular mechanisms that underlie the interactions between dystroglycan and laminin and between laminin and integrins are gradually becoming better understood. As suggested above, perlecan co-operates with laminin in the establishment of a dystroglycan- and integrin-containing lattice on the surface of muscle cells. ${ }^{(50)}$ The failure of the formation of this primary laminin scaffold is thought to be the main cause of congenital muscular dystrophy (CMD), which arises through mutations in the laminin $\alpha 2$ chain (Table 1). There also appears to be a reciprocal and partially compensatory upregulation of $\alpha 7 \beta 1$ integrins or laminin chains where either one is absent or reduced (see Ref. 53 for review). Moreover, it has recently been demonstrated that the dystrophic phenotype can be rescued by the overexpression of the heterologous protein, agrin, which also contains LG domains that are capable of binding to dystroglycan. ${ }^{(98)}$ It would appear, therefore, that there is functional redundancy at the level of the extracellular matrix, where several LG module-containing proteins may be able to substitute for each other in the maintenance of the DGC and muscle basal lamina.

Intermediate filaments and muscular dystrophy Despite the critical role for intermediate filaments in the maintenance of cellular architecture, proof of a direct role for intermediate filaments and intermediate-filament-associated proteins in muscular dystrophy has been somewhat elusive. Various reports have described a desmin-related myopathy, though, in some cases, a direct role for desmin has been ruled out, ${ }^{(54)}$ while, in others, it has been shown to be the direct cause of the disease. ${ }^{(55,56)}$ However, in all cases, it does appear that the mis-assembly or mis-accumulation of desmincontaining intermediate filaments in muscle is responsible for the skeletal and cardiac myopathy associated with these syndromes. Furthermore, deletion of the desmin gene in mice also leads to similar phenotypes. ${ }^{(57)}$ Desmin is believed to be important for the maintenance of Z-line-to-Z-line connections and for Z-line-to-costamere connections (Fig. 1; see also Ref. 24 and references therein). It is not surprising, therefore, that mutations that alter the packing of intermediate filaments would lead to a muscular dystrophy phenotype.

Mutations in plectin, the cytolinker protein capable of connecting actin filaments, intermediate filaments and microtubules, gives rise to a form of muscular dystrophy associated with epidermolysis bullosa. ${ }^{(58)}$ Plectin is known to be associated with hemidesmosomes where it connects intermediate filaments with integrins involved in cell-substrate adhesions. In muscle, mutations in the plectin gene may give rise to reduced cell-substrate contacts through interfering with associations between plectin and desmin, integrins and the DGC in costameres, which would be likely to lead to muscular dystrophy.

\section{Myofibrillar and associated proteins}

It is clear from the discussion above that connections from cytoskeleton to the extracellular matrix are vital for muscle integrity. The maintenance of a direct link between the cytoskeleton and the extracellular matrix has been suggested to be important for force transmission during muscle contraction, and disruptions in this link, especially when dystrophin is absent, lead to membrane fragility and resultant necrosis such as is seen in Duchenne muscular dystrophy. It is not surprising therefore that mutations in proteins that are directly involved in costameric attachments can also lead to muscular dystrophy. Recent progress in elucidating the mechanisms underlying the heterogeneous group of muscular dystrophies known as limbgirdle muscular dystrophy (LGMD: see Table 1) has revealed several proteins involved in the maintenance of the link between extracellular matrix and cytoskeleton. Included among these are the sarcoglycans referred to above, but also proteins such as myotillin and telethonin, sarcomeric proteins associated with the $Z$ discs of striated muscles. ${ }^{(59,60)}$ Myotillin was identified as an $\alpha$-actinin-interacting protein that localised to the I-bands of striated muscle, ${ }^{(59)}$ and was subsequently identified as the gene mutated in LGMD1A. ${ }^{(61)}$ Mutations in the Z-disk protein telethonin give rise to LGMD2G. ${ }^{(62)}$ Telethonin interacts with, and is regulated by the sarcomeric assembly protein titin. These findings suggest that muscle cell integrity may be regulated by two independent roots. One involves physical links between the cytoskeleton and the extracellular matrix via proteins such as dystrophin and the other involves the direct integrity of the myofibrillar apparatus itself. However, these two things are not completely independent. The $Z$ disc structures of striated muscle are in part associated with membrane regions known as costameres (Fig. 1). Costameres have been defined as regions of sarcolemmal attachment to the extracellular matrix, and as being important for the conduction of force during muscle contraction. ${ }^{(1)}$ Therefore, the integrity of the costamere and its underlying Z-disc are important for muscle structure, and mutations that arise in proteins associated with assembly of either structure would be likely to lead to muscle dysfunction. An interesting addition to this story is the finding that the product of the muscle-specific filamin gene known as filamin 2 or $\gamma$-filamin has been found to interact with both $\gamma$ - and $\delta$-sarcoglycans, ${ }^{(63)}$ and also myotillin $^{(64)}$ (Fig. 3). Furthermore, the filamin 2 gene localises to a region of chromosome $7 q$ that is also associated with LGMD1E. $^{(65)}$ It has been proposed ${ }^{(63,64)}$ that filamin may be part of a regulatable link between the membrane and sarcomere. In LGMD2C and LGMD2GF, caused by mutations in the $\gamma$-and $\delta$-sarcoglycan genes respectively, the fraction of filamin 2 localised to the sarcolemma is greatly increased. ${ }^{(63)}$

\section{Calpain and caveolin}

Calpain 3 is mutated in the autosomal recessive LGMD2A ${ }^{(66)}$ and caveolin-3, the muscle-specific isoform of caveolin, is 


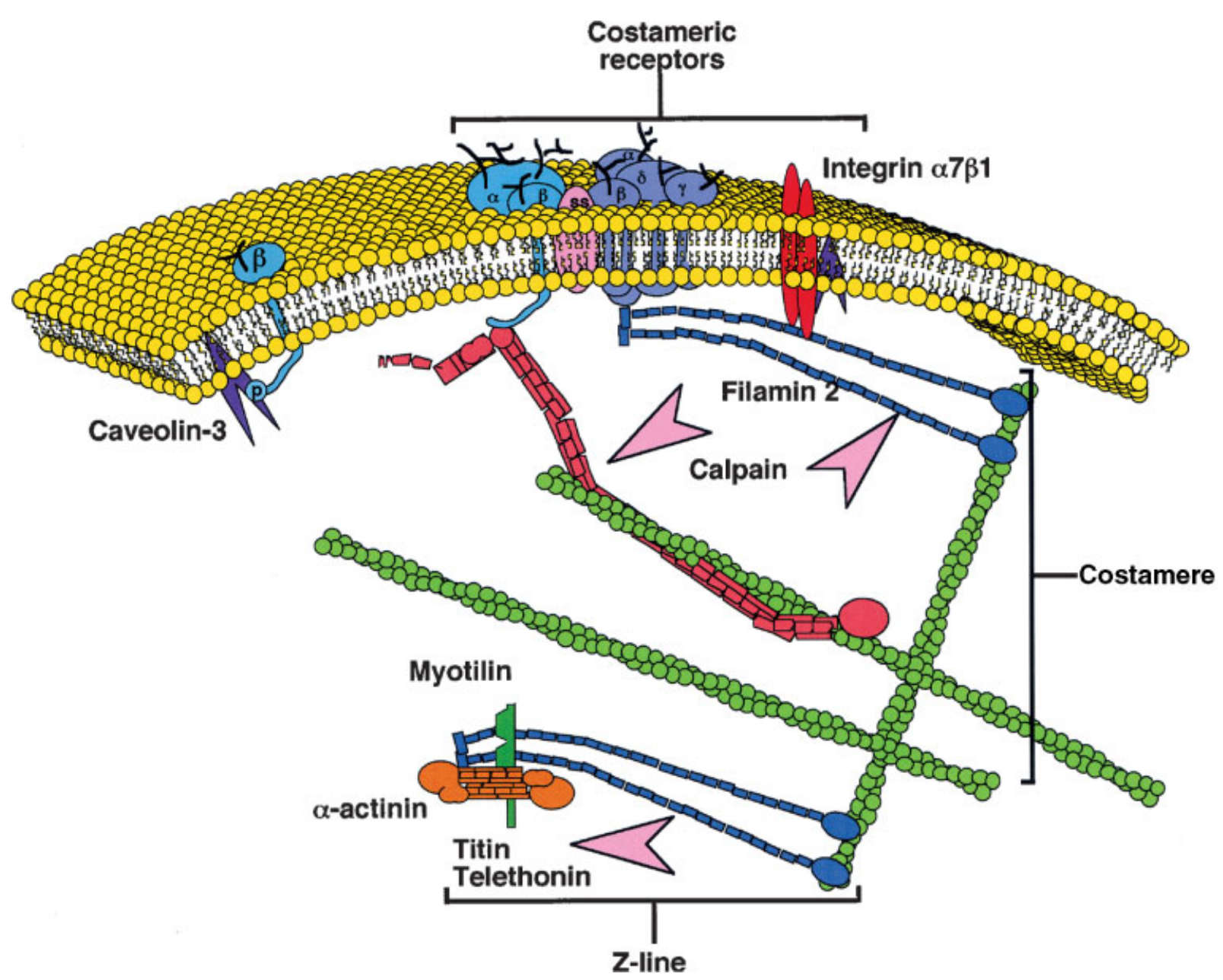

Figure 3. Costameric, myofibrillar and dystrophin-associated proteins in muscle. Scheme showing a possible arrangement of the dystroglycan complex (colours as Fig. 2) with filamin 2, blue; integrin $\alpha 7 \beta 1$, red; caveolin-3, purple; myotilin, green; $\alpha$-actinin, orange; calpain, pink.

known to be mutated in the autosomal dominant LGMD1C ${ }^{(67)}$ (see Table 1). Calpain and caveolin are not myofibrillar proteins, nor are they involved directly in cell adhesion or the cytoskeleton, but they will be discussed here by virtue of their involvement in LGMD and possible common mechanisms of action involving myofibrillar proteins in muscular dystrophy (see 'Mechanisms' below). Calpain-3 has been shown to interact with myofibrils presumably because of its ability to associate with titin. ${ }^{(68)}$ The precise role of calpain-3 in normal muscle is still not clear, but it has been suggested that calpain3 may also serve to regulate filamin 2 function, ${ }^{(63)}$ in a manner similar to the well-documented activity of non-muscle calpain in regulating filamin $1^{(69)}$ and spectrin activity. ${ }^{(70)}$ This again suggests common mechanistic roles for several proteins involved in distinct LGMD types, i.e. calpain, myotillin, telethonin, and potentially filamin 2 (Fig. 3).
Caveolin-3 is the principal structural protein of caveolae in striated muscle, and is associated with the dystrophindystroglycan complex. ${ }^{(71)}$ Mutations in caveolin-3 leads to a muscular dystrophy phenotype, ${ }^{(67)}$ but transgenic overexpression of caveolin 3 in striated muscle also leads to a Duchenne muscular dystrophy phenotype. ${ }^{(72)}$ Caveolin-3 has recently been shown to interact with $\beta$-dystroglycan. ${ }^{(73)}$ Furthermore, it was shown that caveolin-3 interacted with the same binding site on $\beta$-dystroglycan as dystrophin, and that caveolin-3 could compete with dystrophin for binding to $\beta$-dystroglycan. These biochemical findings explain the apparent paradox from the tran sgenic experiments. Despite caveolin-3 being associated with the dystrophin-dystroglycan complex, by competing for binding sites on $\beta$-dystroglycan, it excluded dystrophin binding. This was sufficient to disrupt the link between the actin cytoskeleton and the extracellular matrix leading to a

\section{BioEssays 24.6}


Duchenne muscular dystrophy-like phenotype. In addition, the interactions between caveolin or dystrophin and $\beta$-dystroglycan could potentially be regulated by tyrosine phosphorylation of $\beta$-dystroglycan, ${ }^{(73-75)}$ providing a molecular switch to alter the localisation and subunit composition of the DGC in the sarcolemma (Fig. 3). Furthermore, the potential for tyrosine phosphorylated $\beta$-dystroglycan to interact with other signalling pathways via $\mathrm{SH} 2$ domain-dependent interactions has recently been described. ${ }^{(76)}$

\section{Mechanisms of muscular dystrophy}

The underlying theme of this review has been that compromising the connectivity and physical stability of the muscle membrane through one of several mechanisms leads to muscular dystrophy. The ordered connections between sarcomere structures such as the $\mathrm{Z}$ disc and the costameres are apparently crucial for the maintenance of muscle integrity. Mutations arise at several points in this series of connections, from within the $Z$ discs themselves, as is the case of telethonin and myotillin, through dystrophin and other proteins of the DGC such as sarcoglycans, to laminin in the extracellular matrix. In each case, the perturbation of the ordered ultrastructure and/or the physical disruption of the link is sufficient to weaken the connectivity between cell and matrix leading to myofibre damage. As alluded to in the Introduction, mutations in myofibrillar proteins lead to disorder in the regular spacing of the sarcomeric structure with obvious consequences for the ability of the muscle to contract efficiently. A consequence of the myofibrillar disorder is also likely to be a disruption and irregularity of the spacing of $Z$ discs, resulting in suboptimal spacing of costameric connections to the extracellular matrix, which in turn are also likely to lead to membrane fragility in the wake of the stresses and strains of contraction.

The costameres of striated muscle are analogous structures to the well-studied focal adhesions of fibroblast and other cell types with which they share common protein components such as vinculin, talin, and integrins. Focal adhesions are highly dynamic structures, the assembly and disassembly of which is regulated by the combined effects of Src and FAK tyrosine kinases, Rho family GTPases, mitogen-activated protein kinases and a host of other signalling molecules. The regulation of costamere assembly and disassembly is poorly understood, but once assembled in mature muscle, they are unlikely to be subject to the dramatic and dynamic assembly and disassembly cycles seem with their cousins the focal adhesions. Nevertheless, FAK has been shown to be associated with myofibres and to result in the phosphorylation of sarcoglycans, see above. Costameric structures are unlikely to be completely static and local reassembly following muscle damage and de novo assembly in newly differentiating muscle cells must be somehow regulated. It is conceivable that loss of regulatory proteins such as caveolin 3 or calpain 3 disrupt these processes leading to inefficient assembly or repair. The physiological role of calpain in skeletal muscle is largely unknown, it may be mobilised in damaged muscle for local proteolysis of sarcomeric components in order that new structures can be reassembled, or the action of calpain may be required in order to cleave specific sarcomeric proteins during the assembly process. In either case, mutations in calpain would have a deleterious effect on muscle leading ultimately to dystrophic symptoms. The apparent ability of dystroglycan phosphorylation to serve as a switch to allow interaction with either caveolin or dystrophin, and the clear evidence that caveolin can compete with dystroglycan for dystrophin binding, suggests a regulatory role for caveolin in assembly or disassembly of the DGC. Caveolin, in restricting the availability of dystroglycan by its sequestration to caveolae, could effectively control the amount of mature DGC present at the sarcolemma potentially under the ultimate control of tyrosine phosphorylation.

\section{Conclusions}

The maintenance of muscle structure through the attachment of the myofibrils from the Z-line through the costameres to the sarcolemma and extracellular matrix is vital for both force transmission and maintenance of muscle integrity. Mutations in several proteins that are associated with the connectivity from Z-line to extracellular matrix give rise to muscular dystrophy phenotypes, outlining the importance of this link. However, not all mutations associated with muscular dystrophy involve the structural elements of subsarcolemmal costameric complexes. There are an increasing number of proteins associated with the adhesion structures of muscle that are also signalling molecules or adaptors including calpain and caveolin, or nuclear proteins such as lamin A or emerin. It seems intuitive that disruption of structural elements would lead to muscular dystrophy in a physically active tissue such as muscle, but how mutations in signalling molecules or nuclear proteins give rise to the same phenotypes is less clearly understood. The challenge now is to integrate the pathways connecting structural, cytoskeletal and signalling molecules in order that we can more fully understand the role of the cytoskeleton and cell adhesion in muscular dystrophies.

\section{Acknowledgment}

We are grateful to Dr. K. R. Ayscough for critical reading of the manuscript.

\section{References}

1. Pardo J, Siliciano J, Craig S. A vinculin-containing cortical lattice in skeletal muscle: transverse lattice elements ('costameres') mark the sites of attachment between myofibrils and sarcolemma. Proc Natl Acad Sci USA 1983;80:1008-1012.

2. Berthier C, Blaineau S. Supramolecular organization of the subsarcolemmal cytoskeleton of adult skeletal muscle fibers. A review. Biol Cell 1997;89:413-434.

3. Koenig M, Hoffman EP, Bertelson CJ, Monaco AP, Feener C, Kunkel LM Complete cloning of the Duchenne muscular-dystrophy (DMD) cDNA 
and preliminary genomic organization of the DMD gene in normal and affected individuals. Cell 1987;50:509-517.

4. Koenig M, Monaco AP, Kunkel LM. The complete sequence of dystrophin predicts a rod-shaped cytoskeletal protein. Cell 1988;53:219226.

5. Ervasti JM, Ohlendieck K, Kahl SD, Gaver MG, Campbell KP. Deficiency of a glycoprotein component of the dystrophin complex in dystrophic muscle. Nature 1990;345:315-319.

6. Ervasti JM, Campbell KP. Membrane organisation of the dystrophinmembrane complex. Cell 1991;66:1121-1131.

7. Ohlendieck K, Ervasti JM, Snook JB, Campbell KP. Dystrophinglycoprotein complex is highly enriched in isolated skeletal muscle sarcolemma. J Cell Biol 1991;112:135-148.

8. Campbell KP. Three muscular dystrophies: loss of cytoskeletonextracellular matrix linkage. Cell 1995;80:675-679.

9. Winder SJ, Gibson TJ, Kendrick-Jones J. Dystrophin and utrophin: the missing links! FEBS Lett 1995;369:27-33.

10. Winder SJ. The complexities of dystroglycan. Trends Biochem Sci 2001;26:118-124

11. Ohlendieck K, Campbell KP. Dystrophin-associated proteins are greatly reduced in skeletal-muscle from Mdx mice. J Cell Biol 1991;115:16851694.

12. Cox GA, Sunada Y, Campbell KP, Chamberlain JS. Dp71 can restore the dystrophin-associated glycoprotein complex in muscle but fails to prevent dystrophy. Nature Genet 1994;8:333-339.

13. Greenberg DS, Sunada Y, Campbell KP, Yaffe D, Nudel U. Exogenous Dp71 restores the levels of dystrophin-associated proteins but does not alleviate muscle damage in mdx mice. Nature Genet 1994;8:340-344.

14. Corrado K, Rafael JA, Mills PL, Cole NM, Faulkner JA, Wang K, Chamberlain JS. Transgenic $m d x$ mice expressing dystrophin with a deletion in the actin-binding domain display a "mild Becker" phenotype. J Cell Biol 1996;134:873-884.

15. Amalfitano A, Rafael JA, Chamberlain JS. In: Brown SC, Lucy JA, editors. Dystrophin: Gene, Protein and Cell Biology Cambridge: Cambridge University Press; 1997

16. Beggs AH, Hoffman EP, Snyder JR, Arahata K, Specht L, Shapiro F, Angelini C, Sugita H, Kunkel LM. Exploring the molecular basis for variability among patients with Becker muscular-dystrophy-dystrophin gene and protein studies. Am J Hum Genet 1991;49:54-67.

17. Rybakova IN, Ervasti JM. Dystrophin-glycoprotein complex is monomeric and stabilizes actin filaments in vitro through a lateral association. J Biol Chem 1997;272:28771-28778

18. Rybakova IN, Amman KJ, Ervasti JM. A new model for the interaction of dystrophin with F-actin. J Cell Biol 1996;135:661-672.

19. Winder SJ, Knight AE, Kendrick-Jones J. In: Brown SC, Lucy JA, editors. Dystrophin: Gene, Protein and Cell Biology Cambridge: Cambridge University Press; 1997. pp. 27-55.

20. Winder SJ. The membrane-cytoskeleton interface: the role of dystrophin and utrophin. J Muscle Res Cell Motil 1997;18:617-629.

21. Amann KJ, Guo AW-X, Ervasti JM. Utrophin lacks the rod domain actin-binding activity of dystrophin. J Biol Chem 1999;274:3537535380.

22. Tinsley JM, Potter AC, Phelps SR, Fisher R, Trickett JI, Davies KE. Amelioration of the dystrophic phenotype of $m d x$ mice using a truncated utrophin transgene. Nature 1996;384:349-353.

23. Rybakova IN, Patel JR, Ervasti JM. The dystrophin complex forms a mechanically strong link between the sarcolemma and costameric actin. J Cell Biol 2000;150:1209-1214.

24. Bellin R, Huiatt T, Critchley D, Robson R. Synemin may function to directly link muscle cell intermediate filaments to both myofibrillar Z-lines and costameres. J Biol Chem 2001;276:32330-32337.

25. Porter GA, Dmytrenko GM, Winkelmann JC, Bloch RJ. Dystrophin colocalises with $\beta$-spectrin in distinct subsarcolemmal domains in mammalian skeletal muscle. J Cell Biol 1992;117:997-1005.

26. Henry MD, Campbell KP. A role for dystroglycan in basement membrane assembly. Cell 1998;95:859-870.

27. Williamson RA, Henry MD, Daniels KJ, Hrstka RF, Lee JC, Sunada Y, Ibraghimov-Beskrovnaya O, Campbell KP. Dystroglycan is essential for early embryonic development: disruption of Reichert's membrane in Dag1-null mice. Hum Mol Genet 1997;6:831-841.
28. Cote PD, Moukhles H, Lindenbaum M, Carbonetto S. Chimeric mice deficient in dystroglycans develop muscular dystrophy and have disrupted myoneural synapses. Nature Genet 1999;23:338-342.

29. Yoshida M, Suzuki A, yamamoto H, Noguchi S, Mizuno Y, Ozawa E. Dissociation of the complex of dystrophin and its associated proteins into several groups by $n$-octyl $\beta$-D-glucoside. Eur J Biochem 1994;222:10551061.

30. Holt K, Campbell K. Assembly of the sarcoglycan complex. Insights for muscular dystrophy. J Biol Chem 1998;273:34667-34670.

31. Grady R, Grange R, Lau K, Maimone M, Nichol M, Stull J, Sanes J. Role for alpha-dystrobrevin in the pathogenesis of dystrophin-dependent muscular dystrophies. Nature Cell Biol 1999;1:215-220.

32. Ahn A, Kunkel L. Syntrophin binds to an alternatively spliced exon of dystrophin. J Cell Biol 1995;128:363-371.

33. Blake D, Tinsley J, Davies K, Knight A, Winder S, Kendrick-Jones J. Coiled-coil regions in the carboxy terminal domains of dystrophin and related proteins: potentials for protein-protein interactions. Trends Biochem Sci 1995;20:133-135.

34. Blake D, Nawrotzki R, Peters M, Froehner S, Davies K. Isoform diversity of dystrobrevin, the murine $87-\mathrm{kDa}$ postsynaptic protein. J Biol Chem 1996;271:7802-7810

35. Brenman JA, Chao DS, Xia H, Aldape K, Bredt DS. Nitric oxide synthase complexed with dystrophin and absent from skeletal muscle sarcolemma in Duchenne muscular dystrophy. Cell 1995;82:743-752.

36. Bredt DS. Knocking signalling out of the dystrophin complex. Nature Cell Biol 1999;1:E89-E91.

37. Huang PL, Dawson TM, Bredt DS, Snyder SH, Fishman MC. Targeted disruption of the neuronal nitric oxide synthase gene. Cell 1993;75: 1273-1280.

38. Kameya S, Miyagoe Y, Nonaka I, Ikemoto T, Endo M, Hanaoka K, Nabeshima Y, Takeda S. $\alpha 1$-Syntrophin gene disruption results in the absence of neuronal-type nitric-oxide synthase at the sarcolemma but does not induce muscle degeneration. J Biol Chem 1999;271:21932200.

39. Adams ME, Kramarcy N, Krall SP, Rossi SG, Rotundo RL, Sealock R, Froehner SC. Absence of $\alpha$-syntrophin leads to structurally aberrant neuromuscular synapses deficient in utrophin. J Cell Biol 2000;150: $1385-1398$

40. Adams ME, Mueller HA, Froehner SC. In vivo requirement of the $\alpha$ syntrophin PDZ domain for the sarcolemmal localisation of nNOS and aquaporin-4. J Cell Biol 2001;155:113-122.

41. Lumeng C, Phelps S, Crawford G, Walden P, Barald K, Chamberlain J. Interactions between beta 2-syntrophin and a family of microtubuleassociated serine/threonine kinases. Nature Neurosci 1999;2:611-617.

42. Hasegawa M, Cuenda A, Spillantini M, Thomas G, Buee-Scherrer V, Cohen P, Goedert M. Stress-activated protein kinase-3 interacts with the PZ domain of $\alpha 1$-syntrophin. J Biol Chem 1999;274:12626-12631.

43. Chen Y-W, Zhao P, Borup R, Hoffman E. Expression profiling in the muscular dystrophies: identification of novel aspects of molecular pathophysiology. J Cell Biol 2000;151:1321-1336.

44. Lakonishok M, Muschler J, Horwitz AF. The $\alpha_{5} \beta_{1}$ integrin associates with a dystrophin-containing lattice during muscle development. Dev Biol 1992;152:209-220.

45. Yoshida $T$, Pan $Y$, Hanada $H$, Iwata $Y$, Shigekawa M. Bidirectional signaling between sarcoglycans and the integrin adhesion system in cultured L6 myoblasts. J Biol Chem 1998;273:1583-1590.

46. Taverna D, Disatnik M-H, Rayburn H, Bronson R, Yang J, Rando T, Hynes R. Dystrophic muscle in mice chimeric for expression of $\alpha 5$ integrin. J Cell Biol 1998;143:849-859.

47. Hayashi YK, Chou F-L, Engvall E, Ogawa M, Matsuda C, Hirabayashi S, Yokochi K, Ziober B, Kramer R, Kaufman S, Ozawa E, Goto Y-I, Nonaka I, Tsukahara T, Wang J-Z, Hoffman E, Arahata K. Mutations in the integrin alpha 7 gene cause congenital myopathy. Nature Gemet 1998;19:9497

48. Mayer U, Saher G, Fassler R, Bornemann A, Echtermeyer F, Mark H, Miosge N, Poschl E, Mark KVD. Absence of integrin alpha-7 causes a novel form of muscular dystrophy. Nature Genet 1999;17:318-323.

49. Colognato H, Winkelmann DA, Yurchenco PD. Laminin polymerisation induces a receptor-cytoskeleton network. J Cell Biol 1999;145: $619-631$.

\section{BioEssays 24.6}


50. Henry M, Satz J, Brakebusch C, Costell M, Gustafsson E, Fassler R, Campbell K. Distinct roles for dystroglycan, $\beta 1$ integrin and perlecan in cell surface laminin organisation. J Cell Sci 2001;114:1137-1144.

51. Hohenester E, Tisi D, Talts JF, Timpl R. The crystal structure of a laminin G-like module reveals the molecular basis of $\alpha$-dystroglycan binding to laminin, perlecan and agrin. Mol Cell 1999;4:783-792.

52. Tisi D, Talts JF, Timpl R, Hohenester E. Structure of the C-terminal laminin G-like domain pair of the laminin $\alpha 2$ chain harbouring binding sites for $\alpha$ dystroglycan and heparin. EMBO J 2000;19:1432-1440.

53. Cohn R, Campbell K. Molecular basis of muscular dystrophies. Muscle Nerve 2000;23:1456-1471.

54. Vicart P, Caron A, Guicheney P, Li Z, Prevost M-C, Faure A, Chateau D, Chapon F, Tome F, Dupret J-M, Paulin D, Fardeau M. A missense mutation in the $\alpha \mathrm{B}$-crystallin chaperone gene causes a desmin-related myopathy. Nature Genet 1998;20:92-95.

55. Goldfarb L, Park K-Y, Cervenakova L, gorokhova S, Lee H-S Vasconcelos O, Nagle J, Semino-Mora C, Sivakumar K, Dalakas M. Missense mutations in desmin associated with familial cardiac and skeletal myopathy. Nature Genet 1998;19:402-403.

56. Munoz-Marmol A, Strasser G, Isamat M, Coulombe $P$, Yang $Y$, Roca $X$ Vela E, Mate J, Coll J, Fernandez-Figueras M, Navas-Palacios J, Ariza A Fuchs E. A dysfunctional desmin mutation in a patient with severe generlized myopathy. Proc Natl Acad Sci USA 1998;95:11312-11317.

57. Milner D, Weitzer G, Tran D, Bradley A, Capetanaki Y. Disruption of muscle architecture and myocardial degeneration in mice lacking desmin. J Cell Biol 1996;134:1255-1270.

58. Smith FJD, Eady RAJ, Leigh IM, McMillan JR, Rugg EL, Kelsell DP, Bryant SP, Spurr NK, Geddes JF, Kirtschig G, Milana G, Bono AGD Owaribe K, Wiche G, Pulkkinen L, Uitto J, McLean WHI, Lane EB. Plectin deficiency results in muscular dystrophy with epidermolysis bullosa Nature Genet 1996;13:450-457

59. Salmikangas P MO, Gronholm M, Heiska L, Kere J, Carpen O. Myotilin, a novel sarcomeric protein with two Ig-like domains, is encoded by a candidate gene for limb-girdle muscular dystrophy. Hum Mol Genet 1999;8:1329-1336

60. Valle G, Faulkner G, Antoni AD, Pacchioni B, Pallavicini A, Pandolfo D Tiso N, Toppo S, Trevisan S, Lanfranchi G. Telethonin, a nove sarcomeric protein of heart and skeletal muscle. FEBS Lett 1997;415 163-168.

61. Hauser M, Horrigan S, Salmikangas P, Torian U, Viles K, Dancel R, Tim R, Taivainen A, Bartoloni L, Gilchrist J, Stajich J, Gaskell P, Gilbert J, Vance $J$, Pericak-Vance M, Carpen O, Westbrook C, Speer M. Myotilin is mutated in limb girdle muscular dystrophy $1 \mathrm{~A}$. Hum Mol Genet 2000;9:2141-2147.

62. Moreira E, Wiltshire T, Faulkner G, Nilforoushan A, Vainzof M, Suzuki O, Valle G, Reeves R, Zatz M, Passos-Bueno M, Jenne D. Limb-girdle muscular dystrophy type $2 \mathrm{G}$ is caused by mutations in the gene encoding the sarcomeric protein telethonin. Nature Genet 2000;24:163166.

63. Thompson T, Chan Y-M, Hack A, Brosius M, Rajala M, Lidov H, McNally E, Watkins S, Kunkel L. Filamin 2 (FLN2): a muscle-specific sarcoglycan interacting protein. J Cell Biol 2000;148:115-126.

64. Ven PVD, Wiesner S, Salmikangas P, Auerbach D, Himmel M, Kempa S Hayess K, Pacholsky D, Taivainen A, Schröder R, Carpén O, Fürst D. Indications for a novel muscular dystrophy pathway: filamin, the musclespecific filamin isoform, interacts with myotilin. J Cell Biol 2000;151:235248.

65. Speer M, Vance J, Grubber J, Graham F, Stajich J, Viles K, Rogala A, McMichael R, Chutkow J, Goldsmith C, Tim R, Pericak-Vance M. Identification of a new autosomal dominant limb-girdle muscula dystrophy locus on chromosome 7. Am J Hum Genet 1999;64:556-562.

66. Richard I, Broux O, Allamand V, Fougerousse F, Chiannilkulchai N Bourg N, Brenguier L, Devaud C, Pasturaud P, Roudaut C. Mutations in the proteolytic enzyme calpain cause limb-girdle muscular dystrophytype 2A. Cell 1995;81:27-40.

67. Minetti C, Sotgia F, Bruno C, Scartezzini P, Broda P, Bado M, Masetti E, Mazzocco M, Egeo A, Donati MA, Volonte D, Galbiati F, Cordone G, Bricarelli FD, Lisanti MP, Zara F. Mutations in the caveolin-3 gene cause autosomal dominant limb-girdle muscular dystrophy. Nature Genetics 1998; 18:365-368
68. Kinbara S, Kimura K, Takahashi S, Ishiura M, Sasagawa S, Sorimachi N Shimada N, Tagawa H, Maruyama K, Suzuki K. Muscle-specific calpain, p94, responsible for limb girdle muscular dystrophy type 2A, associates with connectin through IS2, a p94-specific sequence. J Biol Chem 1995;270:31158-31162.

69. Kwak K, Chung S, Kim O, Kang M, Ha D, Chung C. Increase in the level of $\mathrm{m}$-calpain correlates with the elevated cleavage of filamin during myogenic differentiation of embryonic muscle cells. Biochim Biophys Acta 1993;1175:243-249.

70. Hu R, Bennett V. In vitro proteolysis of brain spectrin by calpain I inhibits association of spectrin with ankyrin-independent membrane binding site(s). J Biol Chem 1991;266:18200-18205.

71. Song KS, Scherer PE, Tang Z, Okamoto T, Li S, Chafel M, Chu C, Kohtz DS, Lisanti MP. Expression of caveolin-3 in skeletal, cardiac, and smooth muscle cells. Caveolin-3 is a component of the sarcolemma and cofractionates with dystrophin and dystrophin-associated glycoproteins. J Biol Chem 1996;271:15160-15165

72. Galbiati F, Volonte D, Chu JB, Li M, Fine SW, Fu M, Bermudez J Pedemonte M, Weidenheim KM, Pestell RG, Minetti C, Lisanti MP. Transgenic overexpression of caveolin-3 in skeletal muscle fibers induces a Duchenne-like muscular dystrophy phenotype. Proc Nat Acad Sci USA 2000;97:9689-9694

73. Sotgia F, Lee JK, Das K, Bedford M, Petrucci TC, Macioce $P$, Sargiacomo M, Bricarelli FD, Minetti C, Sudol M, Lisanti MP. Caveolin3 directly interacts with the $\mathrm{C}$-terminal tail of $\beta$-dystroglycan: identification of a central WW-like domain within caveolin family members. J Biol Chem 2000;275:38048-38058.

74. Ilsley JL, Sudol M, Winder SJ. The interaction of dystrophin with $\beta$ dystroglycan is regulated by tyrosine phosphorylation. Cell Signal 2001;13:625-632.

75. Ilsley JL, Sudol M, Winder SJ. The WW domain: linking cell signalling to the membrane cytoskeleton. Cell Signal 2001;14:183-189.

76. Sotgia F, Lee H, Bedford M, Petrucci TC, Sudol M, Lisanti MP. Tyrosine phosphorylation of $\beta$-dystroglycan at its WW domain binfing motif, PPxY, recruits SH2 domain containing proteins. Biochem 2001;40:1458514592.

77. Helbling-Leclerc A, Zhang $X$, Topaloglu H, Cruaud C, Tesson F, Weissenbach J, Tome F, Schwartz K, Fardeau M, Tryggvason K, Guicheney $\mathrm{P}$. Mutations in the laminin alpha 2-chain gene (LAMA2) cause merosin-deficient congenital muscular dystrophy. Nature Genet 1995; 11:216-218

78. Bione S, Maestrini E, Rivella S, Mancini M, Regis S, Romeo G, Tonolio D. Identification of a novel X-linked gene responsible for Emery-Dreifuss muscular dystrophy. Nature Genet 1994;8:323-327.

79. Bonne G, Barletta MD, Varnous S, Becane H, Hammouda E, Merlini L, Muntoni F, Greenberg C, Gary F, Urtizberea J, Duboc D, Fardeau M, Tonolio D, Schwartz K. Mutations in the gene encoding lamin A/C cause autosomal dominant Emery-Dreifuss muscular dystrophy. Nature Genet 1999;21:285-288

80. Kooi AVD, Meegen MV, Ledderhof T, McNally E, Visser MD, Bolhuis P. Genetic localisation of a newly recognised autosomal dominant limbgirdle muscular dystrophy with cardiac involvement (LGMD1B) to chromosome 1q11-12. Am J Hum Genet 1997;60:891-895.

81. Bashir R, Britton S, Strachan T, Keers S, Vafiadaki E, Lako M, Richard I, Marchand S, Bourg N, Argov Z, Sadeh M, Mahjneh I, Marconi G, Passos-Bueno M, Moreira EDS, Zatz M, Beckmann J, Bushby K. A gene related to Caenorhabditis elegans spermatogenesis factor fer- 1 is mutated in limb-girdle muscular dystrophy type 2B. Nature Genet 1998:20:37-42

82. Liu J, Aoki M, Illa I, Wu C, Fardeau M, Angelini C, Serrano C, Urtizberea J, Hentati F, Hamida M, Bohlega S, Culper E, Amato A, Bossie K, Oeltjen J, Bejaoui K, McKenna-Yasek D, Hosler B, Schurr E, Arahat K, Jong PD, Brown R. Dysferlin, a novel skeletal muscle gene, is mutated in Miyoshi myopathy and limb girdle muscular dystrophy. Nature Genet 1998;20: 31-36.

83. Jung D, Leturca F, Sunada Y, Duclos F, Tome FMS, Moomaw C, Merlini L, Azibi K, Chaouch M, Slaughter C, Fardeau M, Kaplan JC, Campbell $\mathrm{KP}$. Absence of gamma-sarcoglycan (35-dag) in autosomal recessive muscular-dystrophy linked to chromosome 13q12. Febs Lett 1996;381: $15-20$. 
84. Roberds SL, Leturcq F, Allamand V, Piccolo F, Jeanpierre M, Anderson RD, Lim LE, lee JC, Tome FMS, Romero NB, Fardeau M, Beckmann JS, Kaplan J-C, Campbell KP. Missense mutations in the adhalin gene linked to autosomal recessive muscular dystrophy. Cell 1994;78:625-633

85. Bonnemann CG, Modi R, Noguchi S, Mizuno Y, Yoshida M, Gussoni E, McNally EM, Duggan DJ, Angelini C, Hoffman EP, Ozawa E, Kunkel LM. $\beta$-sarcoglycan (A3b) mutations cause autosomal recessive muscular dystrophy with loss of the sarcoglycan complex. Nature Genet 1995: 11:266-273.

86. Nigro V, Moreira EDS, Piluso G, Vainzof M, Belsito A, Politano L, Puca A, Passos-Bueno M, Zatz M. Autosomal recessive limbgirdle muscular dystrophy, LGMD2F, is caused by a mutation in the delta-sarcoglycan gene. Nature Genet 1996;14:195198

87. Sicinski P, Geng Y, Ryder-Cook AS, Barnard EA, Darlison MG, Barnard PJ. The molecular basis of muscular dystrophy in the $m d x$ mouse: a point mutation. Science 1989;244:1578-1580.

88. Deconinck AE, Potter AC, Tinsley JM, Wood SJ, Vater R, Young C, Metzinger L, Vincent A, Slater CR, Davies KE. Postsynaptic abnormalities at the neuromuscular junctions of utrophin-deficient mice. J Cell Biol 1997; 136:872-894

89. Grady RM, Merlie JP, Sanes JR. Subtle neuromuscular defects in utrophin-deficient mice. J Cell Biol 1997;136:871-882.

90. Deconinck AE, Rafael JA, Skinner JA, Brown SC, Potter AC, Metzinger L, Watt DJ, Dickson JG, Tinsley JM, Davies KE. Utrophin-dystrophindeficient mice as a model for Duchenne muscular dystrophy. Cell 1997;90:717-727

91. Grady RM, Teng H, Nicholl MC, Cunningham JC, Wilkinson RS, Sanes JR. Skeletal and cardiac myopathies in mice lacking utrophin and dystrophin: a model for Duchenne muscular dystrophy. Cell 1997;90: 729-738.

92. Xu H, Wu XR, Wewer UM, Engvall E. Murine muscular dystrophy caused by a mutation in the laminin $\alpha 2$ (Lama2) gene. Nature Genet 1994;8:297302.

93. Duclos F, Straub V, Moore SA, Venzke DP, Hrstka RF, Crosbie RH, Durbeej M, Lebakken CS, Ettinger AJ, Meulen JVD, Holt KH, Lim LE, Sanes JR, Davidson BL, Faulkner JA, Williamson R, Campbell KP. Progressive muscular dystrophy in $\alpha$-sarcoglycan-deficient mice. J Cell Biol 1998;142:1461-1471.

94. Araishi K, Sasaoka T, Imamura M, Noguchi S, Hama H, Wakabayashi E, Yoshida M, Hori T, Ozawa E. Loss of the sarcoglycan complex and sarcospan leads to muscular dystrophy in $\beta$-sarcoglycan-deficient mice. Hum Mol Genet 1999;8:1589-1598.

95. Hack AA, Ly CT, Jiang F, Clendenin CJ, Sigrist KS, Wollmann RL, McNally EM. $\gamma$-sarcoglycan deficiency leads to muscle membrane defects and apoptosis independent of dystrophin. J Cell Biol 1998;142: 1279-1287.

96. Coral-Vazquez R, Cohn RD, Moore SA, Hill JA, Weiss RM, Davisson RL, Straub V, Barresi R, Bansal D, Hrstka RF, Williamson R, Campbell KP. Disruption of the sarcoglycan-sarcospan complex in vascular smooth muscle: a novel mechanism for cardiomyopathy and muscular dystrophy. Cell 1999;98:465-474.

97. Lebakken C, Venzke D, Hrstka R, Consolino C, Faulkner J, Williamson R, Campbell K. Sarcospan-deficient mice maintain normal muscle function. Mol Cell Biol 2000;20:1669-1677.

98. Moll J., Barzaghi P., Lin S., Bezakova G., Lochmuller H., Engvall E., Muller U., Ruegg MA. An agrin minigene rescues dystrophic symptoms in a mouse model for congenital muscular dystrophy. Nature 2001;413:302-307. (reference added in proof)

\section{BioEssays 24.6}

